\title{
Kallmann syndrome with FGFR1 and KAL1 mutations detected during fetal life
}

\author{
Julie Sarfati ${ }^{1,3,4}$, Claire Bouvattier ${ }^{1,3,6}$, Hélène Bry-Gauillard ${ }^{3,4}$, Alejandra Cartes ${ }^{3,4}$, Jérôme Bouligand 1,2,3,5 \\ and Jacques Young ${ }^{1,2,3,4^{*}}$
}

\begin{abstract}
Kallmann syndrome (KS) patients carrying FGFR1 mutations can transmit the disorder to their offspring as can asymptomatic female carriers of mutations in KAL1. We describe for the first time two cases in which KS was suspected during fetal life because of the family context and malformation detection by fetal ultrasound: syndactyly or unilateral renal agenesis in subjects with respectively FGFR1 and KAL1 mutations. In relevant family history, ultrasound monitoring can detect KS associated signs before birth and thus enable neonatal diagnosis and early management. These observations also underline the importance of genetic counselling for patients who may transmit KS to their offspring.
\end{abstract}

Keywords: Congenital hypogonadotropic hypogonadism, Kallmann, Syndactyly, Kidney agenesis, Prenatal diagnosis, FGFR1, KAL1

\section{Introduction}

Kallmann syndrome (KS; MIM 308700, 147950,244200, $610628,612370,612702)$ is a rare disease characterized by congenital hypogonadotropic hypogonadism $(\mathrm{CHH})$ and an altered sense of smell in both genders [1-3]. KS results from abnormal neural development affecting both the olfactory tracts and $\mathrm{GnRH}$ neuron migration. The genetics of KS is complex [1-3]: more than 15 genes have been linked to the disease, with several modes of transmissions [4-16]. Monogenic forms with $\mathrm{X}$-linked, autosomal dominant and autosomal recessive transmission have been identified [2-7]. Digenic and oligogenic forms with less clear modes of transmission were described more recently [2,3]. The X-linked form is due to mutations in KAL1 (Kallmann syndrome 1), the first responsible gene to be discovered $[4,5]$, presently called ANOS1 (HUGO nomenclature). In this genetic form, females do not generally develop KS $[4,17]$ but carry KAL1 mutation in the heterozygous state [18]. KS patients with KAL1 mutations may have a variety of associated disorders of a neurological or urogenital nature $[2,19]$, the most frequent being mirror movements, renal anomalies (unilateral or bilateral agenesis, horseshoe

\footnotetext{
* Correspondence: jacques.young@bct.aphp.fr

1 Univ Paris-Sud, Le Kremlin Bicêtre F-94276, France

${ }^{2}$ INSERM UMR-1185, Le Kremlin Bicêtre F-94276, France

Full list of author information is available at the end of the article
}

kidney) [20] and neurogenic deafness [2, 19, 21]. The second KS responsible gene to be identified was FGFR1 (Fibroblast Growth Factor Receptor 1); lossof-function mutations of this gene cause a form of KS with autosomal dominant transmission [6, 17, 21]. Other disorders frequently associated with this latter form include midline anomalies (cleft lip or palate) $[2,6,21,22]$, skeletal anomalies of the hands or feet $[23,24]$, dental abnormalities $[6,25]$, and deafness $[6,21]$. Infertility in men and women with KS can be corrected by gonadotropin administration to induce spermatogenesis [26] or ovulation [27, 28]. Given the success of these treatments, there is a growing need for genetic counselling [1, 2, 29, 30]. In addition, early diagnosis of KS would enable more timely management of affected newborns [31].

Herein we report for the first time two cases of KS due to FGFR1 and KAL1 mutations respectively in which the diagnosis was identified before birth via the known genetic basis of KS in the parents and non-invasive monitoring (fetal ultrasound) to identify KS-associated phenotypes. Confirmation of KS at birth enabled early management of the two children.

\section{Case reports}

All the participants or parents gave their written informed consent for hormonal, morphological and genetic analyses, 
performed as part of a non-interventional study, conducted as part of usual patient care. The study was performed in keeping with the provisions of the French Bioethics Law and the Declaration of Helsinki and after approval by the Bicêtre Hospital ethic committee (Comité de protection des personnes Ile de France, Hôpital Bicêtre).

\section{Family 1}

The proband of this family (Fig. 1a) was a 32-year-old woman who consulted for infertility. She had breast development at the age of 12.5 years and menarche at 14.5 years. On consulting for oligomenorrhea (4 menstrual bleeds per year) at the age of 18, she was prescribed a combined oral contraceptive, without an etiological work-up, and subsequently had regular menses. Wishing to become pregnant, she stopped using contraception at 29 years of age. Oligomenorrhea recurred and she failed to conceive despite regular intercourse and her partner's normal sperm count. She then consulted a gynecologist who prescribed her clomiphene citrate. After four rounds of treatment, which led to neither ovulation nor pregnancy, she was referred to our department for an Endocrine consultation.

During the interview she noted no sense of smell (anosmia) that was also present in her maternal grandfather. In addition, she reported poor hearing as well as absent premolars and wisdom teeth (Fig. 1a) [6, 25].

Based on the clinical presentation of infertility in the setting of partial pubertal development and congenital anomalies (anosmia, hearing loss, missing teeth) Kallmann syndrome with partial gonadotropin deficiency was suspected [2, 18]. MRI revealed bilateral agenesis of the olfactory bulbs and of the left olfactory tract, as well as a hypoplastic right olfactory tract, reinforcing our suspicions. Olfactometry [32] confirmed her severe hyposmia. Initial hormonal evaluation of the gonadotropic axis showed an estradiol level of $43 \mathrm{pg} / \mathrm{mL}(\mathrm{N}=25-90)$. The LH and FSH levels were respectively 2.7 IU/L (normal range in the early follicular phase $=3.0-7.0$ ) and 4.6 IU/L (normal range in the early follicular phase $=2.7-7.0$ ). The inhibin B level was $28 \mathrm{pg} / \mathrm{mL}$ (normal range in the early follicular phase $=60-132$ ). A 6-h study of pulsatile LH

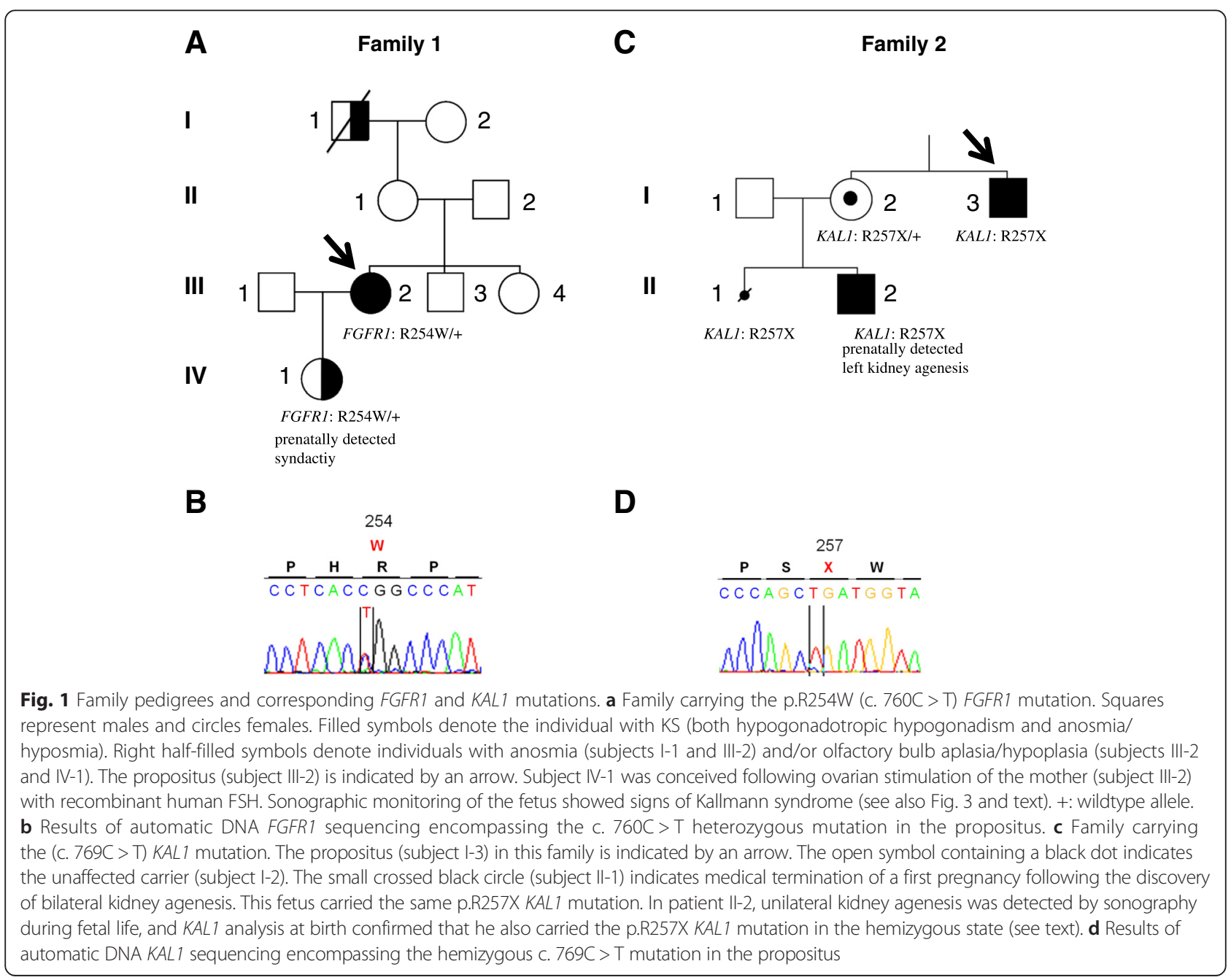


secretion performed as previously reported [33] showed no significant pulses (Fig. 2). Ovarian MRI showed a right ovarian volume of $2.1 \mathrm{ml}$ (normal volume $=6.4 \pm 2.2 \mathrm{ml}$ [34]) with four follicles $2-9 \mathrm{~mm}$ in diameter, and a left ovarian volume of $1.9 \mathrm{ml}$ with 6 follicles all smaller than $4 \mathrm{~mm}$.

Other antepituitary functions (free T4: $16.5 \mathrm{pmol} / \mathrm{L}$ [11-24, 35], TSH: $0.75 \mathrm{mIU} / \mathrm{L}(0.3-4.5)$, peak cortisol $(25 \mu \mathrm{g} / \mathrm{dL} ; \mathrm{N}>18)$ and peak $\mathrm{GH}(45 \mathrm{mIU} / \mathrm{L} ; \mathrm{N}>20)$ in the insulin tolerance test were normal, as was the prolactin $(11 \mathrm{ng} / \mathrm{mL}(\mathrm{N}=10-15)$. Pituitary MRI showed a normal antepituitary size and a normal pituitary stalk. CT Scan showed normal semicircular canals. Audiometry showed partial bilateral deafness predominating at $2000 \mathrm{~Hz}$.

In view of her family history, deafness and dental agenesis suggestive of autosomal KS [2, 6, 21, 25], FGFR1 gene analysis was performed revealing a recurrent heterozygous R254W missense mutation that has previously been shown to be loss-of-function in vitro [36].

As she wished to have children, genetic counselling was provided, during which she was informed that there was a theoretical $50 \%$ risk of transmitting the disease to her children [1, 2, 6, 21, 22, 30].

FSH stimulation (75 IU daily, Gonal-F, Merck Serono, Lyon, France) led to the growth of a dominant follicle. Mono-ovulation was triggered with recombinant hCG (Ovitrelle (R), Merck Serono, Lyon, France), and the luteal phase was supported with hCG [27, 28]. She became pregnant, and fetal ultrasound examination performed at 12 weeks showed no abnormalities. A second US examination during the 23rd week of gestation showed a female fetus with bilateral syndactyly (merging of the 1st and 2nd toes and the 3rd and 4th toes) (Fig. 3a and b), an associated sign described in KS with FGFR1 mutations.
The fetus was assumed to have KS due to maternal transmission of the FGFR1 mutation [2, 6, 24]. Normal delivery took place at the 41st week of gestation. Physical examination of the newborn confirmed the ultrasound anomalies but showed no other malformations. Genetic analysis of a blood sample confirmed the presence of the maternal FGFR1 R254W mutation in the heterozygous state. MRI performed at the age of six months showed hypoplastic olfactory bulbs bilaterally.

\section{Family 2}

The proband was managed in the Endocrinology Department of Bicêtre Hospital, France, for X-linked Kallmann's syndrome diagnosed at age 17 years (Fig. 1c). Physical examination at diagnosis showed micropenis $(<2.5 \mathrm{~cm})$ and bilateral cryptorchidism. Molecular studies revealed a KAL1 mutation (c.769C > T, p.R257X) consistent with his clinical severity [37]. His sister initially refused to be screened for asymptomatic carrier status of this hemizygous KAL1 mutation. During her first pregnancy, bilateral renal agenesis was found in her male fetus and she opted for therapeutic termination at 25 weeks [38]. Subsequently, she accepted KAL1 genetic analysis that confirmed her status as an unaffected carrier of the previously reported KAL1 mutation (p.R257X) [38]. Ultrasound monitoring of a second pregnancy revealed unilateral (left) renal agenesis in the male fetus (Fig. 4), again pointing to X-linked Kallmann's syndrome [19, 20, 39].

At delivery, the newborn's weight and length were normal (weight of $3830 \mathrm{~g}$ and a length of $50 \mathrm{~cm}$ ), but he had micropenis (15 mm;-3SD), descended testes and bilateral testicular hypoplasia (mean testicular volume $0.33 \mathrm{ml}$ (sonography); -3SD). Hormone assays done at age 1 month showed low [31, 40] circulating gonadotropins (FSH: 0.18

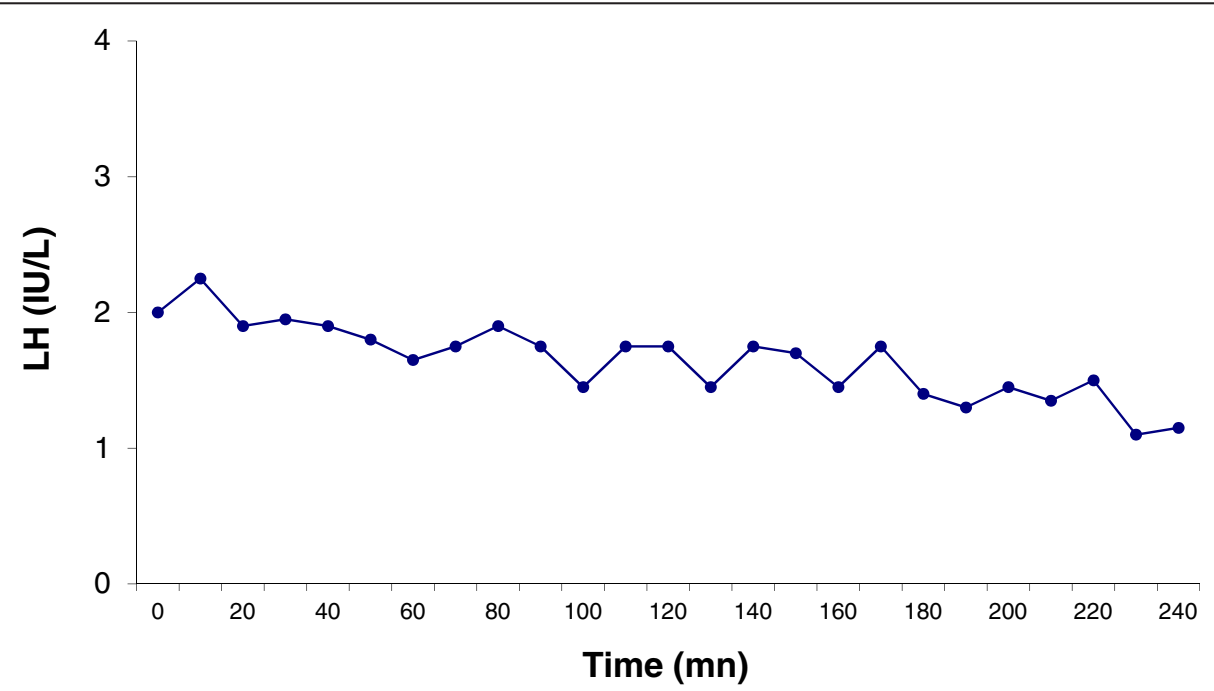

Fig. 2 Baseline secretory pattern of LH release in the female subject III-2 of Fig. 1a during $6 \mathrm{~h}$ of basal evaluation at 10-min intervals. At the time of evaluation, the patient's serum estradiol level was $46 \mathrm{pg} / \mathrm{ml}$, and the serum inhibin B level was $32 \mathrm{pg} / \mathrm{ml}$. No LH pulses were detected 

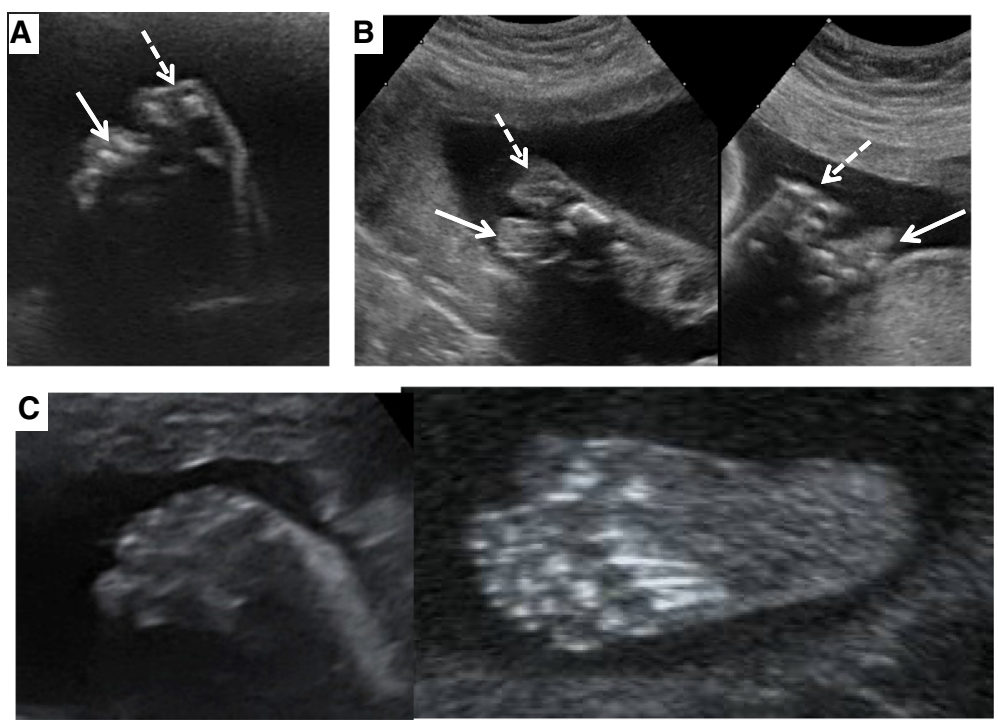

Fig. 3 Ultrasound examination of the feet of the fetus with the p.R254W FGFR1 mutation at 23 weeks of gestation. $\mathbf{a}$ and $\mathbf{b}$ : Ultrasound views respectively of the soles of the right and left feet of the fetus carrying the p.R254W FGFR1 mutation. The dashed white arrow shows the syndactyly of toes I and II, and the solid white arrow that of toes III and IV. c Plantar ultrasound view of a normal fetal foot

(normal range: $0.2-3.5)$; LH: 0.04 IU/L (0.5-6.5)), testosterone $(0.1(0.5-4.8))$ and low testicular peptide levels (inhibin B $24 \mathrm{pg} / \mathrm{mL}$ (75-575); AMH $69 \mathrm{ng} / \mathrm{mL}$ (80-154)), confirming the diagnosis of congenital hypogonadotrophic hypogonadism [31, 40]. Molecular studies done at birth showed that he carried the same KAL1 mutation as his mother and maternal uncle. Postnatal sonography follow-up confirmed the left renal agenesis and compensatory right kidney hypertrophy (see Additional file 1: Figure S1), together with bilateral agenesis of the olfactory bulbs on MRI at age 4 months.

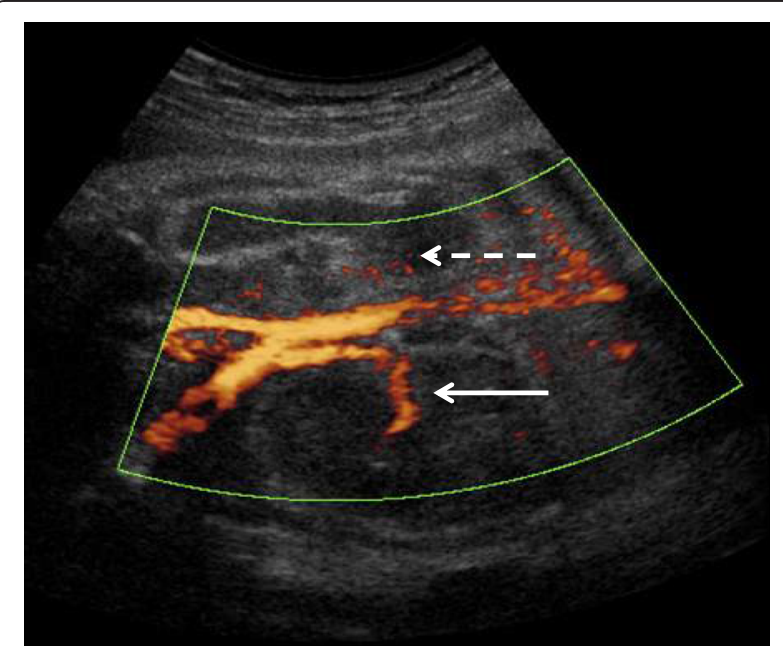

Fig. 4 Renal ultrasound at 28 weeks of gestation in the fetus with the p.R257X KAL 1 mutation. The solid white arrow shows the normal right kidney with its pedicle (Doppler US). The dashed white arrow indicates the absence of the left kidney and renal pedicle
Synkinesia (mirror movements) were also evident and given the frequent association of KAL1 mutations and hearing loss, additional evaluation at 1 year of age was conducted revealing deafness in the child [1, 2, 19, 21, 41]. This early diagnosis enabled timely prosthetic treatment to improve the sensory deficit. In addition, in view of the severe reproductive phenotype with micropenis [31], and with approval from our local ethics committee, we proposed to treat the infant with recombinant human gonadotrophins for inducing phallus growth and testicular development [31]. Both parents gave their written consent. Notably, the mother reported a major factor in her decision was her brother's experience who also had severe KS (cryptorchidism and micropenis) and struggled with sexual disorders and infertility that were not corrected by testosterone treatment or long term combined gonadotropin therapy.

Combination therapy with recombinant human pituitary gonadotrophins (LH and FSH, 75 IU/day each, administered subcutaneously via a pump in order to avoid repeated painful injections) [31, 42] was therefore started when the boy was 1 month old and was continued until the age of 7 months. This treatment was associated with a marked increase in testicle size (from 0.33 to $2.3 \mathrm{ml}$, at sonography) and penis length (from 15 to $38 \mathrm{~mm}$ ), both of which became normal for age. Testicular volume, evaluated by sonography, was still normal $(0.8 \mathrm{~mL})$ one year after the end of gonadotropin therapy.

\section{Discussion}

We describe two cases of Kallmann syndrome in which the diagnosis was strongly suspected during fetal life, in 
view of the familial context and ultrasound detection of foot deformities in one case and renal agenesis in the other case. To our knowledge this is the first time that prenatal diagnosis of KS has been achieved with a non invasive method. One old report, by Bick et al. [43], describes prenatal diagnosis of a complex malformative syndrome comprising KS, due to a chromosomal deletion, but the method used was amniocentesis, a far more invasive approach. The family had a contiguous gene syndrome due to deletion of 9.2 megabases of the Xp22 region, which includes the $K A L 1$, steroid sulfatase (STS) and chondrodysplasia punctata (CDPX1) genes. This prenatal diagnosis was based on the familial context and on a highly elevated DHEAS level in amniotic fluid, indicating severe steroid sulfatase deficiency. Autopsy following therapeutic termination revealed, besides a horseshoe kidney, absent olfactory bulbs and a small penis, indicating that the fetus had KS [4, 5, 43].

In both the cases described here, prenatal screening for signs of KS enabled appropriate management to begin at birth. In the family 2 newborn, diagnostic confirmation by hormonal tests and $K A L 1$ gene analysis enabled us to begin hormone therapy to correct penile and testicular hypotrophy [31, 42]. This early correction of genital hypoplasia is likely to have beneficial consequences for the patient's sexuality and fertility in adulthood [31, 44-47]. Indeed, previous reports have shown that neonatal combined gonadotropin therapy in patients with $\mathrm{CHH} / \mathrm{KS}$ and severe reproductive phenotype, diagnosed at birth can have a short term beneficial effect on testicular endocrine function and on genital development particularly by a marked increase in penile length. It is therefore possible that the normalization of penis size in the neonate period will lead, during subsequent postpubertal virilization, to a normal adult penis size and thus avoid the sexual disorders often reported by men with $\mathrm{CHH}$ and micropenis [31, 44-47].

Moreover, early knowledge of the genotype prompted us to look for other signs associated with this genetic form; in particular, deafness was detected by means of auditory evoked potentials [48], enabling timely prosthetic treatment. Postnatal investigations also allowed us to reassess, by urogenital imaging, the renal malformation detected during fetal life. This confirmed left kidney agenesis and revealed compensatory right kidney hypertrophy (Additional file 1: Figure S1) that preserved renal function. The same postnatal imaging studies showed that the renal disorders were not accompanied by other urogenital anomalies. Finally, the discovery of renal agenesis in the family 2 fetus suggests that this defect develops at a very early stage and does not result from secondary, postnatal atrophy, contrary to statement of some reports [49].

Similarly, in family 1 , following prenatal diagnosis with neonatal confirmation, we were able to seek disorders linked to the relevant FGFR1 mutations in a timely manner.
Brain MRI performed at 6 months showed only agenesis of the olfactory bulbs; no clinically inapparent malformations of the midline were discovered $[2,23,50]$. Hearing tests were normal.

Thus, early diagnosis of KS and knowledge of the genotype in the two cases reported here allowed us to look for signs that might otherwise have been overlooked at birth, potentially delaying the diagnosis until puberty [51]. Indeed, disorders associated with KS are generally discovered only when KS itself is diagnosed, usually at the age of puberty, ruling out timely treatment [51]. Early diagnosis also avoids unnecessary investigations and possible misdiagnosis, and enables replacement therapy to begin at the physiological age of puberty, thereby avoiding the frequent psychological impact of delayed pubertal development [44-47].

These two cases highlight the frequency of direct transmission of KS by patients carrying mutations in FGFR1 or KAL1 [1, 3, 6]. Likewise, when KS associated with KAL1 mutation is diagnosed in a male patient, it is necessary to conduct exhaustive investigations based on family genetic screening for heterozygous healthy carriers $[1,2,29,30]$. Indeed, given the almost complete penetrance of this phenotype in this X-linked form, a male fetus that inherits the mutated allele from his mother will have a high probability of developing KS. These family studies are also necessary in autosomal dominant forms, as the risk of disease transmission to the offspring is theoretically $50 \%$. In the case of FGFR1 mutations, genetic counselling is complicated by the variable penetrance of both cardinal and associated signs, even within the same family $[2,6,21,37,50]$.

However, even if the mutations in KAL1 and FGFR1 are very penetrant, other genes contributing to oligogenic forms may have variable expressivity and incomplete penetrance or contribute to the severity of phenotypes in patients carrying deleterious KAL1 or FGFR1 mutations $[2,3]$. This is a limitation of the experience reported here because not all Kallmann cases associated with KAL1 or FGFR1 mutations will be transmitted as reported herein $[2,3]$.

One interesting feature of family 1 was the proband's phenotype. The patient reported having normal pubertal development with menarche at age 14, and said her doctors had not attempted to determine the cause of her oligomenorrhea. In our experience, this is quite a common situation in partial female hypoganodotrophic hypogonadism. Indeed, it is principally the complete form with absent puberty that is taught in medical school and described in textbooks, even though a number of case reports and some studies describe the existence of partial forms of IHH in which breast and pubic hair development are present, despite primary amenorrhea in $95 \%$ of cases $[2,52,53]$. Cases of IHH with oligomenorrhea are far 
more rarely reported [18, 54]. The case described here stresses the importance of diagnosing these very partial forms of KS before considering medically assisted procreation, given the implications for genetic counselling and the need to closely monitor these pregnancies. Finally, the propositus of family 1 presents a paradigme of cases of female KS patient who are not diagnosed until much later in life. There is a wellreported gender discrepancy between male and female $\mathrm{CHH} / \mathrm{KS}$ cases with approximately 3-5 males diagnosed for each female case. This may be in fact a bias of ascertainment as females are often started on empiric therapy without a full work-up [2, 18, 51-54].

\section{Additional file}

Additional file 1: Figure S1. Post-natal kidney ultrasound performed in the neonate carrying the p.R257X KAL 1 mutation (see also Fig. 3). Panel A: Left posterior fossa view showing the absent left kidney. S: spleen. Panel B: Right kidney ultrasound revealing compensatory hypertrophy (dotted line indicate kidney length $(65 \mathrm{~mm})$.

\section{Competing interests}

The authors declare that they have no competing interests.

\section{Authors' contributions}

JY conceived and designed the study. JS participated in its design and coordination, and analyzed the data. HB-G and AC, CB carried out clinical care and analyzed the data and contributed to draft the manuscript. $\mathrm{JB}$ carried out the molecular genetic studies, participated in the sequence alignment, and contributed to draft the manuscript. JS and JY wrote the article. All authors read and approved the final manuscript.

\section{Acknowledgements}

This work was supported by Agence Nationale de la Recherche (ANR-09-GENO-017-01). We also thank the European COST Action BM1105 for its support.

\begin{abstract}
Author details
'Univ Paris-Sud, Le Kremlin Bicêtre F-94276, France. ${ }^{2}$ INSERM UMR-1185, Le Kremlin Bicêtre F-94276, France. ${ }^{3}$ Assistance Publique-Hôpitaux de Paris, Bicêtre Hospital, 78 rue du Général Leclerc, Le Kremlin-Bicêtre F-94275, France. ${ }^{4}$ Department of Reproductive Endocrinology, 78 rue du Général Leclerc, Le Kremlin-Bicêtre F-94275, France. ${ }^{5}$ Molecular Genetics and Hormonology Department, 78 rue du Général Leclerc, Le Kremlin-Bicêtre F-94275, France. ${ }^{6}$ Department of Pediatric Endocrinology, 78 rue du Général Leclerc, Le Kremlin-Bicêtre F-94275, France.
\end{abstract}

Received: 23 February 2015 Accepted: 20 May 2015 Published online: 09 June 2015

\section{References}

1. Young J. Approach to the male patient with congenital hypogonadotropic hypogonadism. J Clin Endocrinol Metab. 2012;97:707-18.

2. Boehm U, Bouloux PM, Dattani M, de Roux N, Dodé C, Dunkel L, et al. European Consensus Statement on Congenital Hypogonadotrophic Hypogonadism: Pathogenesis, diagnosis, and treatment. Nat Rev Endocrinol 2015; in press.

3. Mitchell AL, Dwyer A, Pitteloud N, Quinton R. Genetic basis and variable phenotypic expression of Kallmann syndrome: towards a unifying theory. Trends Endocrinol Metab. 2011;22:249-58.

4. Legouis R, Hardelin J-P, Levilliers J, Claverie J-M, Compain S, Wunderle V, et al. The candidate gene for the X-linked Kallmann syndrome encodes a protein related to adhesion molecules. Cell. 1991;67:423-35.
5. Franco B, Guioli S, Pragliola A, Incerti B, Bardoni B, Tonlorenzi R, et al. A gene deleted in Kallmann's syndrome shares homology with neural cell adhesion and axonal path-finding molecules. Nature. 1991;353:529-36.

6. Dodé C, Levilliers J, Dupont JM, De Paepe A, Le Dû N, Soussi-Yanicostas N, et al. Loss-of-function mutations in FGFR1 cause autosomal dominant Kallmann syndrome. Nat Genet. 2003;33:463-5.

7. Dodé C, Teixeira L, Levilliers J, Fouveaut C, Bouchard P, Kottler ML, et al. Kallmann syndrome: mutations in the genes encoding prokineticin- 2 and prokineticin receptor-2. PLoS Genet. 2006;2:e175.

8. Falardeau J, Chung WC, Beenken A, Raivio T, Plummer L, Sidis Y, et al. Decreased FGF8 signaling causes deficiency of gonadotropin-releasing hormone in humans and mice. J Clin Invest. 2008;118:2822-31.

9. Kim HG, Kurth I, Lan F, Meliciani I, Wenzel W, Eom SH, et al. Mutations in CHD7, encoding a chromatin-remodeling protein, cause idiopathic hypogonadotropic hypogonadism and Kallmann syndrome. Am J Hum Genet. 2008:83:511-9.

10. Kim HG, Ahn JW, Kurth I, Ullmann R, Kim HT, Kulharya A, et al. WDR11, a WD protein that interacts with transcription factor EMX1, is mutated in idiopathic hypogonadotropic hypogonadism and Kallmann syndrome. Am J Hum Genet. 2010;87:465-79.

11. Tornberg J, Sykiotis GP, Keefe K, Plummer L, Hoang X, Hall JE, et al. Heparan sulfate 6-O-sulfotransferase 1 , a gene involved in extracellular sugar modifications, is mutated in patients with idiopathic hypogonadotrophic hypogonadism. Proc Natl Acad Sci U S A. 2011;108:11524-9.

12. Young J, Metay C, Bouligand J, Tou B, Francou B, Maione L, et al. SEMA3A deletion in a family with Kallmann syndrome validates the role of semaphorin $3 \mathrm{~A}$ in human puberty and olfactory system development. Hum Reprod. 2012;27:1460-5.

13. Hanchate NK, Giacobini P, Lhuillier P, Parkash J, Espy C, Fouveaut C, et al. SEMA3A, a gene involved in axonal pathfinding, is mutated in patients with Kallmann syndrome. PLoS Genet. 2012;8:e1002896.

14. Pingault V, Bodereau V, Baral V, Marcos S, Watanabe Y, Chaoui A, et al. Loss-of-function mutations in SOX10 cause Kallmann syndrome with deafness. Am J Hum Genet. 2013;92:707-24.

15. Miraoui H, Dwyer AA, Sykiotis GP, Plummer L, Chung W, Feng B, et al. Mutations in FGF17, IL17RD, DUSP6, SPRY4, and FLRT3 are identified in individuals with congenital hypogonadotropic hypogonadism. Am J Hum Genet. 2013;92:725-43.

16. Kotan LD, Hutchins Bl, Ozkan Y, Demirel F, Stoner H, Cheng PJ, et al. Mutations in FEZF1 cause Kallmann syndrome. Am J Hum Genet. 2014;95:326-31.

17. Sato N, Katsumata N, Kagami M, Hasegawa T, Hori N, Kawakita S, et al. Clinical assessment and mutation analysis of Kallmann syndrome 1 (KAL1) and fibroblast growth factor receptor 1 (FGFR1, or KAL2) in five families and 18 sporadic patients. J Clin Endocrinol Metab. 2004;89:1079-88.

18. Shaw ND, Seminara SB, Welt CK, Au MG, Plummer L, Hughes VA, et al. Expanding the phenotype and genotype of female GnRH deficiency. J Clin Endocrinol Metab. 2011;96:E566-76.

19. Hardelin JP, Levilliers J, Young J, Pholsena M, Legouis R, Kirk J, et al. Xp22.3 deletions in isolated familial Kallmann's syndrome. J Clin Endocrinol Metab. 1993;76:827-31.

20. Georgopoulos NA, Koika V, Galli-Tsinopoulou A, Spiliotis BE, Adonakis G, Keramida MK, et al. Renal dysgenesis and KAL1 gene defects in patients with sporadic Kallmann syndrome. Fertil Steril. 2007;88:1311-7.

21. Albuisson J, Pêcheux C, Carel JC, Lacombe D, Leheup B, Lapuzina P, et al. Kallmann syndrome: 14 novel mutations in KAL1 and FGFR1 (KAL2). Hum Mutat. 2005;25:98-9.

22. Dodé C, Fouveaut C, Mortier G, Janssens S, Bertherat J, Mahoudeau J, et al. Novel FGFR1 sequence variants in Kallmann syndrome, and genetic evidence that the FGFR1C isoform is required in olfactory bulb and palate morphogenesis. Hum Mutat. 2007;28:97-8.

23. Zenaty D, Bretones P, Lambe C, Guemas I, David M, Léger J, et al. Paediatric phenotype of Kallmann syndrome due to mutations of fibroblast growth factor receptor 1 (FGFR1). Mol Cell Endocrinol. 2006;25:78-83.

24. Villanueva C, Jacobson-Dickman E, Xu C, Manouvrier S, Dwyer AA, Sykiotis GP, et al. Congenital hypogonadotropic hypogonadism with split hand/foot malformation: a clinical entity with a high frequency of FGFR1 mutations. Genet Med. 2014; 13:doi: 10.1038/gim.2014.166.

25. Bailleul-Forestier I, Gros C, Zenaty D, Bennaceur S, Leger J, de Roux N. Dental agenesis in Kallmann syndrome individuals with FGFR1 mutations. Int J Paediatr Dent. 2010;20:305-12. 
26. Büchter D, Behre HM, Kliesch S, Nieschlag E. Pulsatile GnRH or human chorionic gonadotropin/human menopausal gonadotropin as effective treatment for men with hypogonadotropic hypogonadism: a review of 42 cases. Eur J Endocrinol. 1998;139:298-303.

27. Kousta E, White DM, Piazzi A, Loumaye E, Franks S. Successful induction ovulation and completed pregnancy using recombinant human luteinizing hormone and follicle stimulating hormone in a woman with Kallmann's syndrome. Hum Reprod. 1996;11:70-1.

28. Burgués S. Spanish Collaborative Group on Female Hypogonadotrophic Hypogonadism: The effectiveness and safety of recombinant human LH to support follicular development induced by recombinant human FSH in WHO group I anovulation: evidence from a multicentre study in Spain. Hum Reprod. 2001;16:2525-32.

29. Layman LC. Clinical genetic testing for Kallmann syndrome. J Clin Endocrinol Metab. 2013;98(5):1860-2.

30. Au MG, Crowley Jr WF, Buck CL. Genetic counseling for isolated GnRH deficiency. Mol Cell Endocrinol. 2011;346:102-9.

31. Bouvattier C, Maione L, Bouligand J, Dodé C, Guiochon-Mantel A, Young J. Neonatal gonadotropin therapy in male congenital hypogonadotropic hypogonadism. Nat Rev Endocrinol. 2011;8:172-82.

32. Eloit C, Trotier D. A new clinical olfactory test to quantify olfactory deficiencies. Rhinology. 1994;32:57-61.

33. Bouligand J, Ghervan C, Tello JA, Brailly-Tabard S, Salenave S, Chanson P, et al. Isolated familial hypogonadotropic hypogonadism and a GNRH1 mutation. N Engl J Med. 2009;360:2742-8.

34. Deb S, Campbell BK, Clewes JS, Pincott-Allen C, Raine-Fenning NJ. Intracycle variation in number of antral follicles stratified by size and in endocrine markers of ovarian reserve in women with normal ovulatory menstrual cycles. Ultrasound Obstet Gynecol. 2013;41:216-22.

35. Quinton R, Duke VM, Robertson A, Kirk JM, Matfin G, de Zoysa PA, et al. Idiopathic gonadotrophin deficiency: genetic questions addressed through phenotypic characterization. Clin Endocrinol. 2001;55:163-74.

36. Koika V, Varnavas $P$, Valavani $H$, Sidis $Y$, Plummer L, Dwyer A, et al. Comparative functional analysis of two fibroblast growth factor receptor 1 (FGFR1) mutations affecting the same residue (R254W and R254Q) in isolated hypogonadotropic hypogonadism (IHH). Gene. 2013;516:146-51.

37. Salenave S, Chanson P, Bry H, Pugeat M, Cabrol S, Carel JC, et al. Kallmann's syndrome: a comparison of the reproductive phenotypes in men carrying KAL1 and FGFR1/KAL2 mutations. J Clin Endocrinol Metab. 2008;93:758-63.

38. Teixeira L, Guimiot F, Dodé C, Fallet-Bianco C, Millar RP, Delezoide AL, et al. Defective migration of neuroendocrine $\mathrm{GnRH}$ cells in human arrhinencephalic conditions. J Clin Invest. 2010;120:3668-72.

39. Kirk JM, Grant DB, Besser GM, Shalet S, Quinton R, Smith CS. Unilateral renal aplasia in X-linked Kallmann's syndrome. Clin Genet. 1994:46:260-2.

40. Grumbach MM. A window of opportunity: the diagnosis of gonadotropin deficiency in the male infant. J Clin Endocrinol Metab. 2005;90:3122-7.

41. Massin N, Pêcheux C, Eloit C, Bensimon JL, Galey J, Kuttenn F, et al. X chromosome-linked Kallmann syndrome: clinical heterogeneity in three siblings carrying an intragenic deletion of the KAL-1 gene. J Clin Endocrinol Metab. 2003;88:2003-8

42. Bougnères $P$, François $M$, Pantalone $L$, Rodrigue $D$, Bouvattier $C$, Demesteere $E$, et al. Effects of an early postnatal treatment of hypogonadotropic hypogonadism with a continuous subcutaneous infusion of recombinant follicle-stimulating hormone and luteinizing hormone. J Clin Endocrinol Metab. 2008;93:2202-5.

43. Bick DP, Schorderet DF, Price PA, Campbell L, Huff RW, Shapiro LJ, et al. Prenatal diagnosis and investigation of a fetus with chondrodysplasia punctata, ichthyosis, and Kallmann syndrome due to an Xp deletion. Prenat Diagn. 1992;12:19-29.

44. Smith N, Quinton R. Kallmann syndrome. BMJ. 2012;345:e6971.

45. Dwyer AA, Quinton R, Morin D, Pitteloud N. Identifying the unmet health needs of patients with congenital hypogonadotropic hypogonadism using a web-based needs assessment: implications for online interventions and peer-to-peer support. Orphanet J Rare Dis. 2014;9:83.

46. Varimo T, Hero M, Laitinen EM, Sintonen H, Raivio T. Health-related quality of life in male patients with congenital hypogonadotropic hypogonadism. Clin Endocrinol (Oxf). 2014; doi: 10.1111/cen.12701.

47. Dwyer AA, Quinton R, Pitteloud N, Morin D. Psychosexual development in men with congenital hypogonadotropic hypogonadism on long-term treatment: a mixed methods study. Sex Med. 2015;3(1):32-41. doi:10.1002/sm2.50.
48. Thompson DC, McPhillips H, Davis RL, Lieu TL, Homer CJ, Helfand M. Universal newborn hearing screening: summary of evidence. JAMA. 2001;286:2000-10.

49. Deeb A, Robertson A, MacColl G, Bouloux PM, Gibson M, Winyard PJ, et al. Multicystic dysplastic kidney and Kallmann's syndrome: a new association? Nephrol Dial Transplant. 2001;16:1170-5.

50. Maione L, Benadjaoud S, Eloit C, Sinisi AA, Colao A, Chanson P, et al. Computed tomography of the anterior skull base in Kallmann syndrome reveals specific ethmoid bone abnormalities associated with olfactory bulb defects. J Clin Endocrinol Metab. 2013:98:E537-46.

51. Kaplan JD, Bernstein JA, Kwan A, Hudgins L. Clues to an early diagnosis of Kallmann syndrome. Am J Med Genet A. 2010;152A:2796-801.

52. Pitteloud N, Meysing A, Quinton R, Acierno Jr JS, Dwyer AA, Plummer L. Mutations in fibroblast growth factor receptor 1 cause Kallmann syndrome with a wide spectrum of reproductive phenotypes. Mol Cell Endocrinol. 2006;254-55:60-9.

53. Bry-Gauillard H, Trabado S, Bouligand J, Sarfati J, Francou B, Salenave S, et al. Congenital hypogonadotropic hypogonadism in females: clinical spectrum, evaluation and genetics. Ann Endocrinol (Paris). 2010;71:158-62.

54. Brioude F, Bouligand J, Trabado S, Francou B, Salenave S, Kamenicky P, et al. Non-syndromic congenital hypogonadotropic hypogonadism: clinical presentation and genotype-phenotype relationships. Eur J Endocrinol. 2010;162:835-51

\section{Submit your next manuscript to BioMed Central and take full advantage of:}

- Convenient online submission

- Thorough peer review

- No space constraints or color figure charges

- Immediate publication on acceptance

- Inclusion in PubMed, CAS, Scopus and Google Scholar

- Research which is freely available for redistribution 